\title{
NEWS OF THE ADVERTISERS
}

\section{Colin Russel Is HoNORED}

Hundreds of employees of Russel Brothers Limited, and their families gathered at the Community Arena last March to honor Colin Russel, one of the founders of the industry, who recently retired from the presidency of the company. On behalf of all Russel employees, a beautiful silver tray and silver tea service were presented Mr. Russel. The event, ostensibly "Russel Night". at the Arena, was turned into a great expression of loyalty and appreciation for Mr. Russel. It was sponsored on behalf of all Russel Employees by Local 2837 United Steel Workers of America and 'The Russel Recreation Club. An excellent program of ice sports preceded and followed the ceremony in honor of Mr. Russel.

Ald. Percy England, an employee of the company for many years, and an official of Local 2837 was chairman for the evening, announcing the sports events, and introducing the visitors, government officials and business men with whom the company had relations in Owen Sound, as well as members of community organizations with which Mr. Russel has been associated in the city.

President of the Board of Trade, Ivor Wagner referred to the "family party" of Russel employees as "something wonderful", at which the employees were gathered to honor the retiring president of one of Owen Sound's great industries. In his official capacity as liaison officer between Canada and U.S.A. during the war, he had ample opportunity to learn of the splendid war effort of company and men in building ships which were so badly needed. Not only had Mr. Russel helped to build the industry but he had given unstintingly to Owen Sound community life. "Owen Sound should be proud of and grateful to Russel Brothers", Mr. Wagner said. "They have gathered together a group of workers, who, with management, are building a greater and better industry." 